\title{
Remote sensing of aerosol properties during intense smog events over Lahore (Pakistan)
}

\author{
Salman Tariq ${ }^{1, *}$, Sumayia Mehmood ${ }^{1}$, Aiman Nisa $^{1}$, Zia ul-Haq $^{1}$, Usman Mehmood $^{2}$ \\ ${ }^{1}$ Dept. of Space Science, University of the Punjab, Remote Sensing, GIS and Climatic Research \\ Lab (National Center of GIS and Space ApplicationsLahore), Pakistan. \\ ${ }^{2}$ University of Management and Technology, Lahore, Pakistan. \\ *Corresponding author: salmantariq_pu@yahoo.com
}

\begin{abstract}
In recent years, smog has been one of the main concerns in heavily populated urban areas like Lahore (Pakistan) and Kanpur (India). Atmospheric pollutants like aerosols play an important role in smog. In this paper, aerosol types are identified in smog episodes, based on Aerosol Robotic Network (AERONET) data, during 4-year period i.e., 2015-2018. Aerosols are classified based on fine mode fraction (FMF) and single scattering albedo (SSA). One of the main aerosol types which are abundant in every smog episode is Black Carbon (BC) aerosol while dust is present throughout the year. $\mathrm{BC}$ is responsible for radiation imbalance and is considered the main component in climate changes at regional and global levels. Furthermore, time series of aerosol optical depth (AOD) during smog episodes is used to identify the variability of aerosol burden in the atmosphere. Backward trajectories from the HYSPLIT model are used to trace the origin of aerosols during the days of maximum AOD.
\end{abstract}

Keywords: Aerosol properties; Kanpur; Lahore; remote sensing; smog.

\section{Introduction}

For developing countries like Pakistan, air pollution has now become a critical challenge because of growing industries and road traffic causing a dramatic increase in the emission of air pollutants. Due to rapid urbanization vehicular emissions mixes with dust which badly affects the climate (Nawazish et al., 2017). Rapid industrialization, burning of fossil fuels, and the excessive use of vehicles are contributing to pollution (Shah et al., 2020). Industrial chemicals harmfully affect the air quality (Hameed, 2020). The climatic changes and ecological degradation are generally associated with enhanced $\mathrm{CO}_{2}$ that is majorly contributing to environmental imbalances (Mehmood \& Tariq, 2020). The location of $\mathrm{CO}_{2}$ is eventual in causing severe climatic changes and correlated problems
(Mehmood, 2020). After so many efforts of the advanced world to lessen the environmental releases, it is still affecting the climate due to the production and discharges from the established countries, producing the same pollution (Mehmood et al., 2020).

In the process of modeling the climate, the most causes of ambiguity are aerosols, which affect the atmosphere, by changing the cloud processes and radiation budget (Sabbah et al., 2012). In atmosphere, aerosols are originated from natural and different anthropogenic activities. Aerosols originated from natural emissions are mostly primary aerosols (e.g., dust). Secondary aerosols are mainly fine particles, originated because of anthropogenic activities. Incomplete burning of fossil fuels, biofuels 
and biomass generates $\mathrm{BC}$ aerosols, considered as one of the main components responsible for climate change. It is suggested in recent researches that $\mathrm{BC}$ is responsible for both regional and global changes in climates (Jacobson \& Mark Z, 2002). In the atmosphere, BC is increasing due to the emissions of vehicle exhaust, fossil fuels, and agricultural burning (Tariq \& Ali, 2016). Over South Asia, aerosols have gained enough attention in past years due to their influence on air quality, visibility, radiation imbalance, and health of human beings.

Smog is produced by a combination of fog and smoke. The city of London encountered an elongated week event of "killer smog" in December 1952 due to the burning of coal (Chung et al., 2015). In Pakistan, especially the city of Lahore is immersed by a dense blanket of smog during winter for the last few years. Smog is produced when sunlight reacts with organic volatile compounds and nitrogen oxide. These pollutants enter in the atmosphere through industrialization, power plants and automobiles.

In urban environments, severe smog can occur due to $\mathrm{BC}$ aerosols along with suitable weather conditions (Mira et al., 2008). Soot emission related with coal burning was accountable for London smog, having both $\mathrm{BC}$ and organic compounds as main constituents (Brimblecombe \& Peter, 1978). By the utilization of other fuels such as gasoline instead of coal, another view of air pollution arose in US and California.

In this paper, aerosol types in smog episodes are identified, based on Aerosol Robotic Network (AERONET) data, during 4-year period i.e. 2015-2018. Aerosols are classified into six different types using fine mode fraction (FMF) and single scattering albedo (SSA). FMF provides the quantifiable information related to size distribution of aerosols while SSA tells us the scattering and absorption characteristics of aerosols. Furthermore, to discuss atmospheric conditions during smog days, vertical sounding profiles are used.

\section{Study Area}

As a second most populous city of Pakistan, Lahore $\left(31.56^{\circ} \mathrm{N} 74.35^{\circ} \mathrm{E}\right)$ is located in the upper Indus plain, with a population of over 10 million (Tariq \& Ul-Haq, 2020). Climate of Lahore is classified as BSh (semi-arid monsoonal climate) according to Köppen and Geiger classification (Ashiq, ur Rehman and Khan, 2020). Lahore is affected form heavy aerosol pollution including fine mode particles particularly in winter due to fossil fuel combustion and different anthropogenic activities and dust throughout the year.

Kanpur is a large city famous for its industry, located in state of Uttar Pradesh in Northern India with 2.767 million population. According to Köppen and Geiger, climate of Kanpur is Cwa (monsson influenced humid subtropical climate) (Mishra et al., 2020). Kanpur is affected by

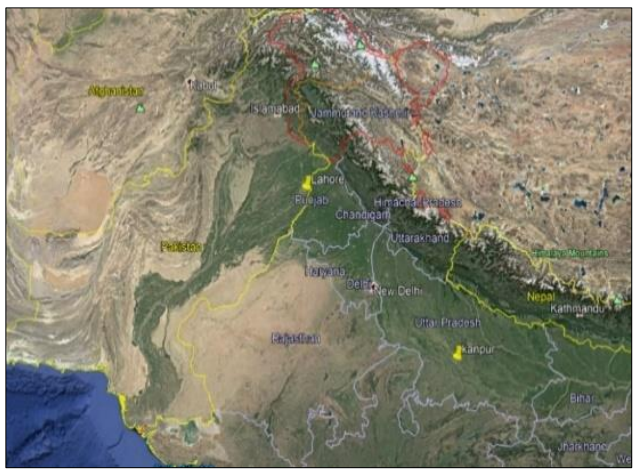

Fig. 1. Study area (Lahore and Kanpur).

dense smoky conditions in post monsoon due to massive crop burning. (Chen et al., 2016).

\subsection{Climate of Lahore}

The monsoon season in Lahore starts from the end of June till the start of September. The highest temperature was observed to be 
$48^{\circ} \mathrm{C}$ in June while the minimum temperature recorded to be $-2^{\circ} \mathrm{C}$ in January. Seasonal average temperature is lowest in winter $\left(13.8^{\circ} \mathrm{C}\right)$ and highest in summer $\left(31.3^{\circ} \mathrm{C}\right)$. The yearly rainfall is of $489 \mathrm{~mm}$. The average yearly relative humidity recorded as $37.9 \%$. According to the climatological conditions in Lahore, it has four main seasons. Seasons of Lahore are categorized as winter (DJF), spring (MAM), summer (JJA) and fall (SON). In summer season intense rainfall $(176.3 \mathrm{~mm})$ occurs.

In summer season, dust storms occurring frequency is $48.3 \%$ while in the winter season their frequency is just $1.5 \%$ (Ali et al., 2014). Asia is mostly affected by the dust coming from Taklamakan and Gobi Desert (Lee et al., 2010). Dust concentrations show negative correlation with rainfall (Al-Dousari \& Al-Awadhi, 2012).

\section{Materials and Methods}

\subsection{AERONET (Aerosol Robotic Network)}

AERONET is a ground-based project for the remote sensing of aerosols founded by NASA and PHOTONS (Photométrie pour le Traitement Opérationnel de Normalisation Satellitaire) that offers a calibration for a ground-based aerosol monitoring on local to global level. For more than 400 sites over the entire globe, AERONET provides the data of Aerosol optical depth (AOD), aerosol inversion products and precipitable water in 3 Levels. Level 1.0 data is unscreened, Level 1.5 data is cloud screened and quality controlled, Level 2.0 data is quality assured. AOD, precipitable water and inversion products are all derived from these three levels (Ali et al., 2014) although some supplementary checks for quality may be implemented. AOD from direct sun and SSA from inversion algorithms are used in order to classify aerosols types.
Level 2.0 data is preferred, however where level 2.0 data is unavailable, level 1.5 data is used. One can download AERONET data directly from the official website of AERONET.(Https://aeronet.gsfc.nasa.gov/n ew_web/index.html)

\subsubsection{Versions of AERONET}

The algorithm has two versions: Version 1.0 and Version 2.0. In 2003, version 1 became operational with employment of assurance criteria (level 2). Version 2 have numerous developments which include changes inversion mode, the input data and the standards for quality assured. The version 1 uses the inversion algorithm that provides the spherical particle shape model and spheroidal aerosol model. Version 2 products are easy; simplified. It calculates the percentage of spherical particle scattering which is known as sphericity parameter.

\subsection{HYSPLIT (Hybrid Single Particle} Lagrangian Integrated Trajectory)

The National Oceanic and Atmospheric Administration (NOAA) Air Resources Laboratory's (ARL) Hybrid Single-Particle Lagrangian Integrated Trajectory model (HYSPLIT)" (Draxler et al., 1998) is a whole system to calculate the trajectory of air mass and distribution of air pollutants in atmosphere. The HYSPLIT model can be used on PC, Mac, or Linux platforms using only a single processor. A registered version of the model is also available that adds up the ability of using the model with current forecast meteorological data (Stein et al., 2015). The most common application of this model includes the analysis of backtrajectory used to verify the origin of air masses.

The calculations of back-trajectory have been one of the most prominent features of HYSPLIT, used in many studies. The 
trajectories offer a simple calculation of source-receptor relationships, but a single trajectory cannot sufficiently denote the turbulent mixing processes that is experienced by the air parcels during its transport. Coupling the back-trajectory calculations with a lagrangian dispersion component however can produce a more accurate representation of the link between the receptor and the sources affecting it. In order to predict the backward trajectory, HYSPLIT model is used with the archived data.

In this study, one source location is chosen which is our study area Lahore and GDAS 0.5-degree input data is used to compute archived trajectories. GDAS 0.5degree is the only data available online for current location except for GDAS 1-degree. Trajectories are computed during the days of November when AOD was maximum. Each backward trajectory was calculated for $48 \mathrm{~h}$ duration. The height of backward trajectories from the ground is chosen to be $500 \mathrm{~m}, 1000 \mathrm{~m}$ and $1500 \mathrm{~m}$. This model can be used from the HYSPLIT official website (http://ready.arl.noaa.gov/HYSPLIT.php).

\section{Methodology for Classification of Aerosols}

The classification of Aerosols is based on size and radiation absorptivity, thus producing four unique categories which are

- Absorbing fine-mode

- Absorbing course-mode

- Non-absorbing fine-mode

- Non-absorbing course-mode

Absorbing fine-mode aerosols are classified as Black Carbon (BC) as its optical properties are well known. BC consists of pure carbon in several linked forms. In climatology, $\mathrm{BC}$ is a climate forcing agent. By absorbing sunlight, BC warm up the Earth. BC stays in the atmosphere for only several days to weeks. $\mathrm{BC}$ aerosols are further classified into Moderately Absorbing (MA), Slightly Absorbing (SA) and Highly Absorbing (HA) (Higurashi \& Nakajima, 2002).

To differentiate absorbing from nonabsorbing aerosols SSA is used and to conclude size of aerosols FMF at $550 \mathrm{~nm}$ is used. SSA is the ratio of scattering efficiency to total extinction efficiency. SSA has no units and its value of 1 suggests that the extinction of all particles is because of scattering; conversely, when SSA is 0 then the extinction of all particles is owed by absorption. Distribution of aerosols in atmospheric is generally bimodal.

Smaller particles are known as the fine mode or accumulation mode aerosols, having radius between 0.1 and 0.25 microns. Coarse mode particles are the larger ones with the radius laying between 1.0-2.5 microns. On the other hand, the FMF of aerosols is the fraction of fine mode AOD to the total AOD. Threshold of FMF determines the dominant size mode of aerosols. AERONET inversion algorithm slightly overestimates fine-mode AOD and underestimate coarse-mode AOD. To tackle this estimation problem, 0.2 safety margin in the threshold of FMF is adopted. As a result, aerosol having FMF $>0.6$ are distinguished as fine-mode aerosols whereas to classify the aerosol as coarse-mode aerosol the FMF should be $<0.4$. The aerosols lying within the margin of 0.2 that is from 0.4 to 0.6 inclusive, are classified as mixture of both modes.

Those aerosols which have FMF greater than 0.6 are further classified as nonabsorbing if SSA is greater than 0.95 and as $\mathrm{BC}$ if SSA is lesser than 0.95. On contrary, coarse-mode aerosols having SSA greater than 0.95 are classified as uncertain aerosols and those with SSA less than 0.95 are classified as dust aerosols (Lee et al., 2010). 


\section{Results and Discussions}

4.1 Classification of Aerosols over Lahore and Kanpur

Aerosols over Lahore and Kanpur are divided into 5 classes i.e., uncertain, dust, mixture, NA and $\mathrm{BC}$. BC is further divided into 3 classes as $\mathrm{SA}, \mathrm{MA}$ and $\mathrm{HA}$ on the basis of SSA at $440 \mathrm{~nm}$ and FMF at $500 \mathrm{~nm}$. Percentage of overall data represented by each class in Lahore and Kanpur is shown in figure 2.

Figure 2 shows classification of aerosols over Kanpur. The most dominant type of aerosol is dust with frequency of $52 \%$ and these aerosols are found throughout the year followed by NA which are mostly found in winters. All types of $\mathrm{BC}$ are found in the order $\mathrm{HA}>\mathrm{SA}>\mathrm{MA}$ while lowest frequency

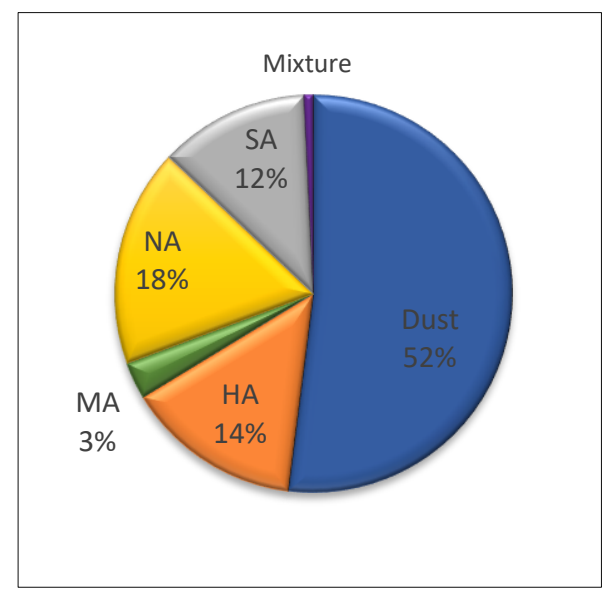

Fig. 2. Classification of aerosols over Kanpur.

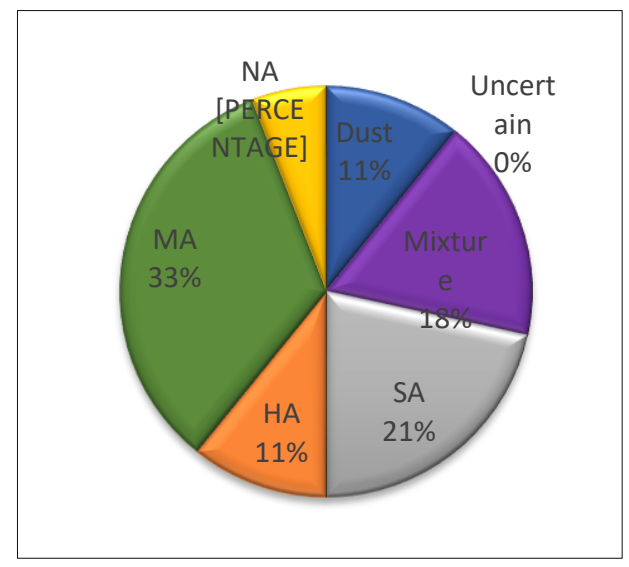

Fig. 3. Classification of aerosols over Lahore. is observed for mixtures. Figure 3 exhibits that for Lahore the most dominant type of the aerosol is MA, accounting for $33 \%$ of all the aerosols and second dominant type of aerosols is SA which have frequency of $21 \%$. Mixture class has frequency of $18 \%$ while HA and dust both have frequency of $11 \%$. The rare concentration of aerosol type detected is NA $(6 \%)$.

\subsection{Temporal Distribution of Aerosols}

The yearly classification of aerosols from the year 2015-2018 are shown in figure 4 and 5. Every year shows different concentrations of different particles over Lahore. In 2015, the most often identified aerosol type is MA and mixture followed by $\mathrm{BC}$, whereas dust and $\mathrm{NA}$ are rarely detected. In 2016 the most often identified aerosol type is MA, whereas the rarely observed aerosol is dust. In 2017, the frequently occurring aerosol type is MA like previous years. In 2018, the most often identified aerosol type is dust and mixture, whereas HA and NA followed by BC are rarely identified. From these results we can conclude that Lahore is mainly affected by $\mathrm{BC}$ aerosols.

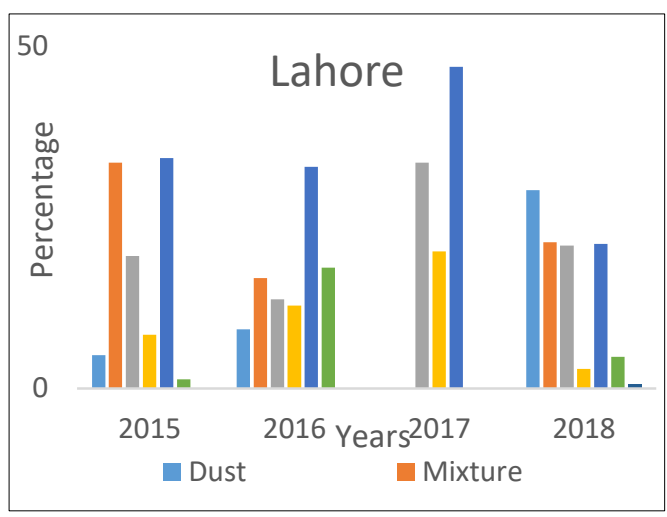

Fig. 4. Temporal distribution of aerosols over Lahore. 
$\mathrm{BC}$ are formed due to natural and anthropogenic activities. Anthropogenic sources are primarily comprised of coal combustion, car exhaust emissions, oil, biomass burning and several fossil fuels (Bond et al., 2007). Burning of crops is also a main source of $\mathrm{BC}$ aerosols. Figure 5 shows that dust is the most dominant aerosol type over Kanpur during all time period. NA and SA values are prominent in the all years.

We have used $\mathrm{S}$ for months having smog and $\mathrm{N}$ for months without smog in figure 6 and 7. Figure 6 shows that dust is present mostly all year long. During smog episodes, mostly NA and BC are observed, although concentration of different types of BC differs. During the years of 2015 and 2016, all three types of $\mathrm{BC}$ are present in almost same concentration. But during 2017 and 2018, SA is maximum and MA is minimum. In normal days dust is dominant followed by
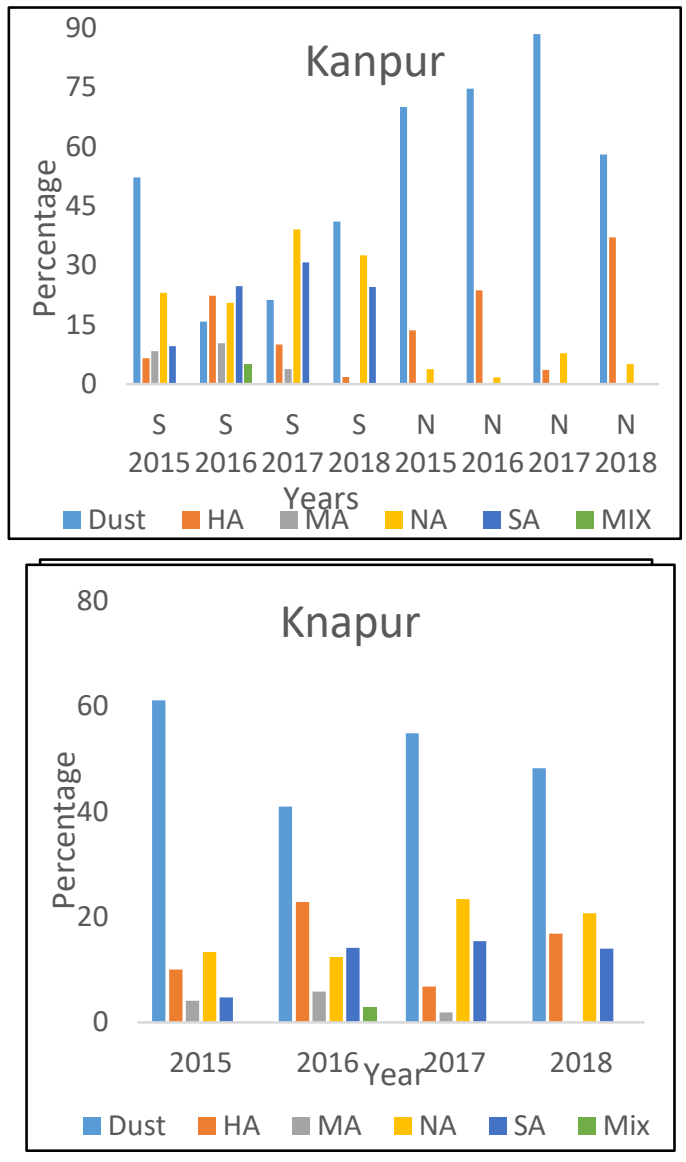

Fig. 5. Temporal distribution of aerosols over Kanpur.
HA with least concentration of SA, MA and mixture.

Figure 7 is presenting distribution of aerosols over Lahore during smog episodes and normal days. During smog episodes most dominant aerosol type is MA. This shows that $\mathrm{BC}$ aerosols are dominant during smog episodes.

$\mathrm{BC}$ aerosols are further divided into three types on the basis of SSA. SA (slightly absorbing) having the highest SSA $(0.90<$ SSA $\leq 0.95$ ), MA (moderately absorbing)

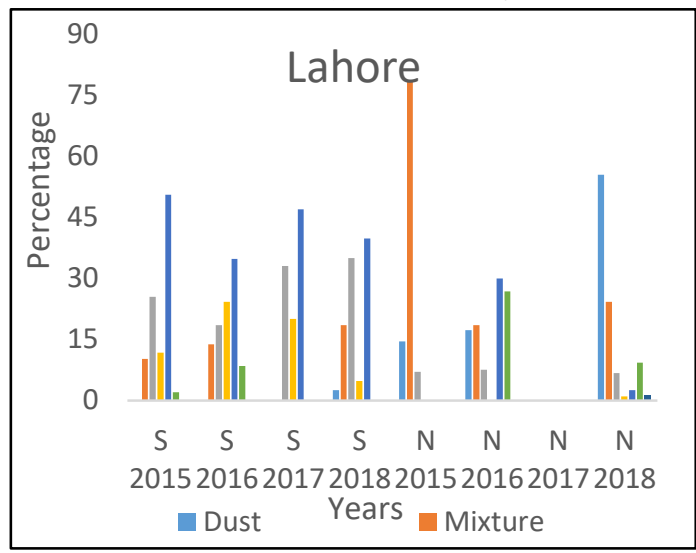

Fig. 7. Aerosol types over Lahore during Smog episodes and Normal days.

with moderate SSA values $(0.85<\mathrm{SSA}$ $\leq 0.90$ ) and HA (highly absorbing) with lowest SSA values $(0.85 \leq \mathrm{SSA})$ (Lee et al., 2010). During dry seasons, the most dominant aerosols type is $\mathrm{BC}$ throughout the Asia region. Although the frequency of these anthropogenic aerosols can be further explained primarily by the source of emissions and partially by relative humidity. SSA of anthropogenic aerosols is affected by the change in relative humidity.

In Asia, SA concentrations are less as compared to MA and HA. As a developing region, this area has become a main source of $\mathrm{BC}$ emission because of excessive combustion of fossil fuels for domestic, industrial and transportation purposes. This combustion leads to the emission of $\mathrm{BC}$ aerosols with low SSA i.e., MA and HA. Different types of $\mathrm{BC}$ are emitted due to change in burning process (Lee et al., 2010). 
Flaming stage of burning grasses produce $\mathrm{HA}$ and smoldering stage forest burning

produces NA in Africa and South America respectively (Lee et al., 2010). Lahore experience immense crop burning in late autumn and early winter season, which is also a flaming stage of burning producing more HA aerosols.

Lahore is one of the main industrial and urban sites in the Punjab region. Dust is transported from southern Punjab during summer months, industrial, soot and road emissions add $\mathrm{BC}$ content in the atmosphere throughout the year. BC concentrations peaks up in winter season when burning process is increased for heating purposes. High BC content (low SSA, MA, HA) is observed in dry seasons and low BC content (high SSA, SA, NA) in wet months (Lee et al., 2010).

Mixture is also present in every year except 2017. Small concentration of NA is present in 2015 and 2016. But no general trend for normal days is observed. In 2015, NA is dominant with small concentrations of dust and SA. In 2016, almost same concentration of all types is present except HA and uncertain aerosols. No data was available for 2017. For 2018, most dominant aerosol type is dust followed by mixture with small concentration of other classes.

\subsection{Variability of Single Scattering Albedo}

In the current work, we obtained SSA from measurements of sun/sky radiance (Nakajima et al., 1996; Dubovik et al., 2000). The SSA displays different spectral response for diverse types of aerosols. For industrial and BC aerosols SSA decreases with wavelength while for desert dust aerosol SSA increases with wavelength (Dubovik et al., 2002).

Figure 8 and 9 shows the spectral variation of SSA (Ali et al., 2014) for the month of November from year 2015 to 2018 over Lahore. There is a reasonable dependence of SSA over different wavelengths. With the rise in wavelength after $675 \mathrm{~nm} \mathrm{SSA}$ is reduced, as interaction between solar radiations and absorbing aerosols is very low (Singh et al., 2004; Yu et al. 2009). Over Lahore, NA shows highest value of SSA among all types of aerosols with mean values ranging from 0.98-0.95 over the wavelength ranging from 440$1020 \mathrm{~nm}$. And for Kanpur, this range is from 0.94-0.91 for NA. This aerosol type is more dominant over winter and post monsoon season when the relative humidity is relatively greater than other seasons (Chen et al., 2016).

For SA, SSA values range from 0.920.93 over Lahore. MA and mixture show

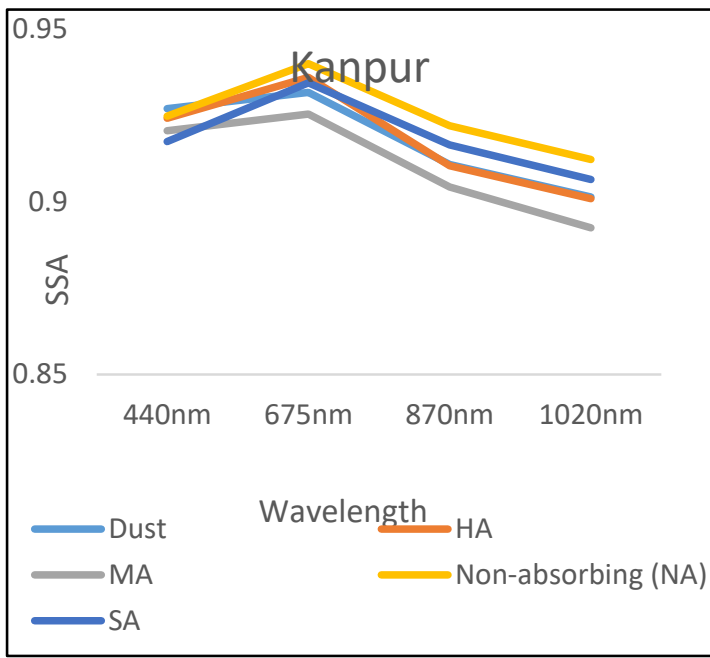

Fig. 9. SSA variations of different aerosol types over Kanpur

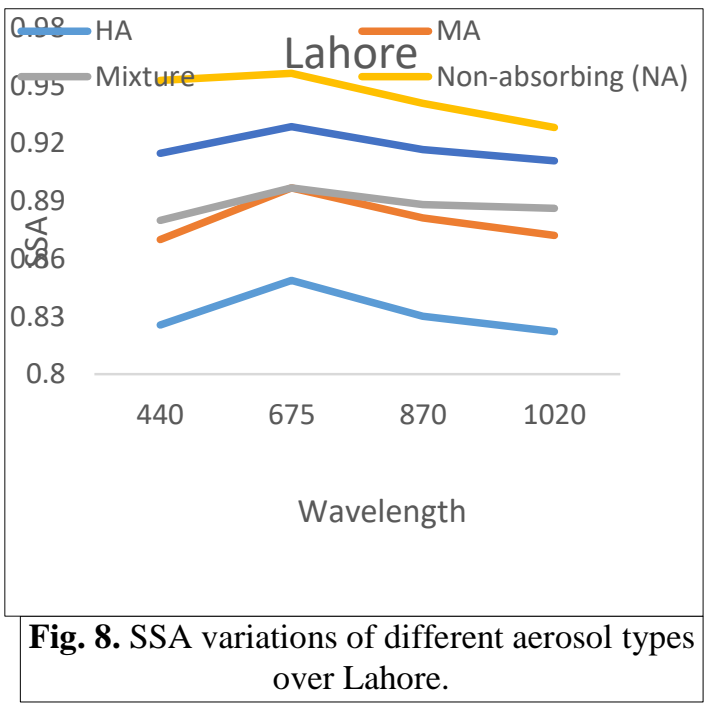


almost same behavior with the values between 0.84-0.90. HA shows least SSA values having strong absorbing properties. Aerosols over Kanpur show almost same SSA trends with dust showing highest SSA and SA with the least values.

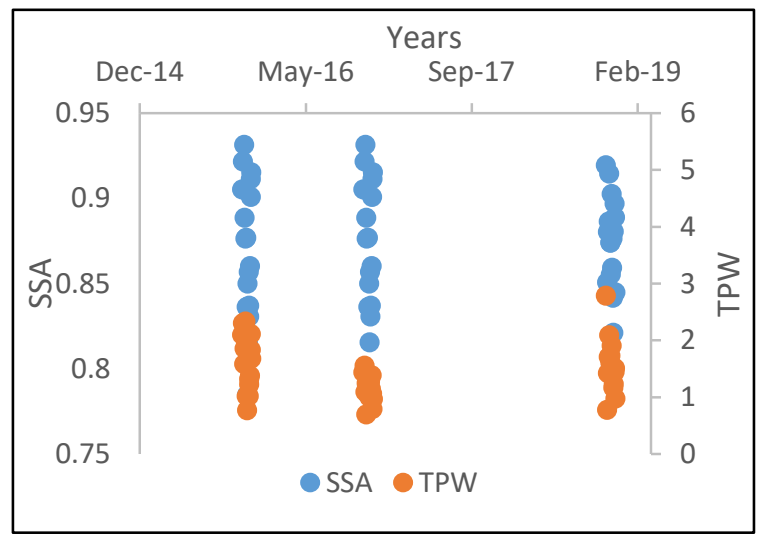

Fig. 10. Time series of SSA and TPW over Lahore.

To examine the variations of SSA with regard to Total Precipitable Water (TPW) over Lahore, time series between SSA and TPW is plotted over Lahore as shown in Fig 10. The trend between SSA and TPW is linear. The Pearson correlation coefficient between SSA and TPW is found to be 0.04 .

\subsection{Variability of Fine Mode Fraction}

FMF is the fraction of fine mode AOD to the complete AOD at $500 \mathrm{~nm}$, where fine and coarse mode aerosols are defined, by their radius ranges from $0.1-0.25 \mu \mathrm{m}$ and 1.0 to $2.5 \mu \mathrm{m}$ correspondingly (Aloysius et al., 2009). Range of FMF from 0 to 1 means coarse mode particle to fine mode particle which provides the quantifiable information related to size distribution (Kim et al., 2007; Kedia et al., 2014).

It is related to the spectral dependence of the absorption of particle size in addition it has the potential to illustrate the prevailing absorbing aerosol types (Giles et al., 2011). Figure 11, 12 and 13 shows the time series

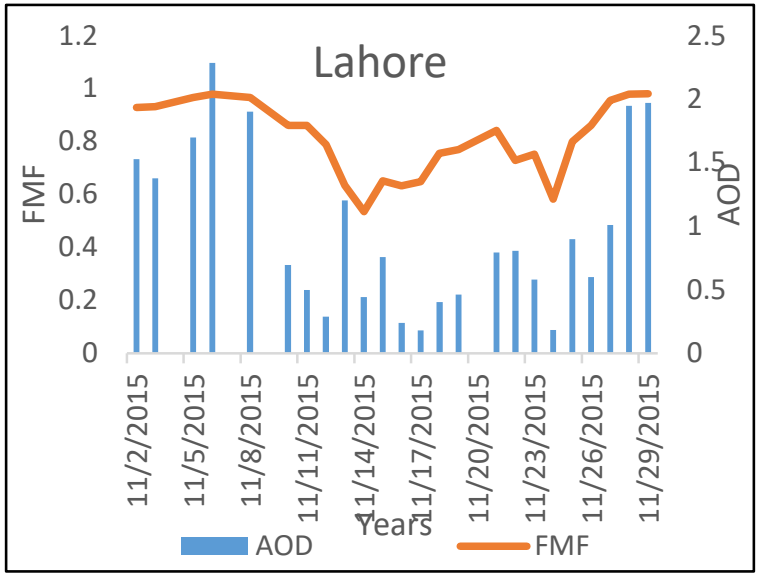

Fig. 11. FMF and AOD time series over Lahore during 2015.

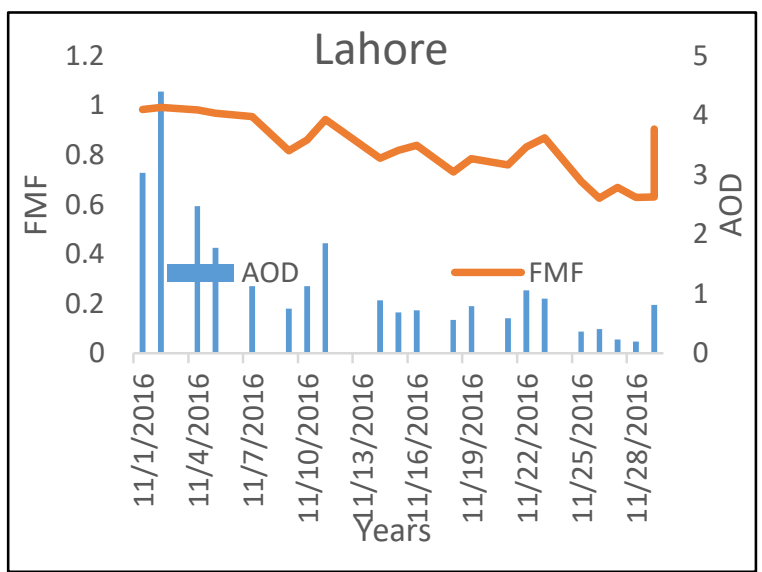

Fig. 12. FMF and AOD time series over Lahore during 2016.

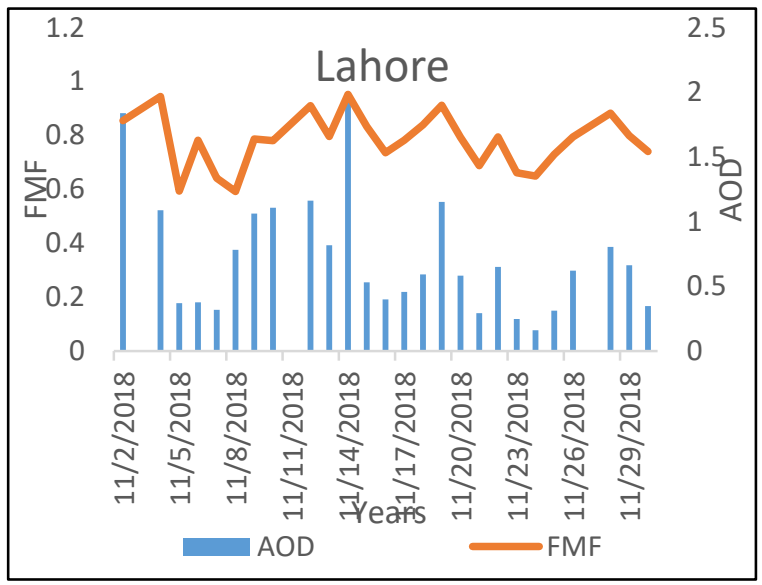

Fig. 13. FMF and AOD time series over Lahore during 2018. 
of FMF and AOD for the month of November of years 2015, 2016 and 2018 respectively. The figures show that when FMF increased, AOD is also increased during this selected time period. Maximum AOD and FMF during the month of November indicate the presence of smog episodes in these days.

\subsection{Variability of Aerosol Optical Depth}

AOD is defined as the "measure of atmospheric extinction through vertical atmospheric column. More aerosols are in the column, the higher the value of AOD. It is the significant parameter used to estimate aerosol burden in the atmosphere (Tariq et al., 2015). Maximum AOD during the month of November shows increased chances of smog. Probability of smog increase when the humidity is also increased during the time when AOD is maximum.

Figure 14, 15 and 16 shows the variations of AOD and humidity for the year 2015, 2016, and 2018. The increasing trend of AOD is different for different years. In 2015, AOD is increasing from the start of month and is maximum at 11 November and then AOD remains constant afterwards. The FMF also shows the similar trend. In 2016 AOD has maximum values in the start of the month then decrease afterwards.

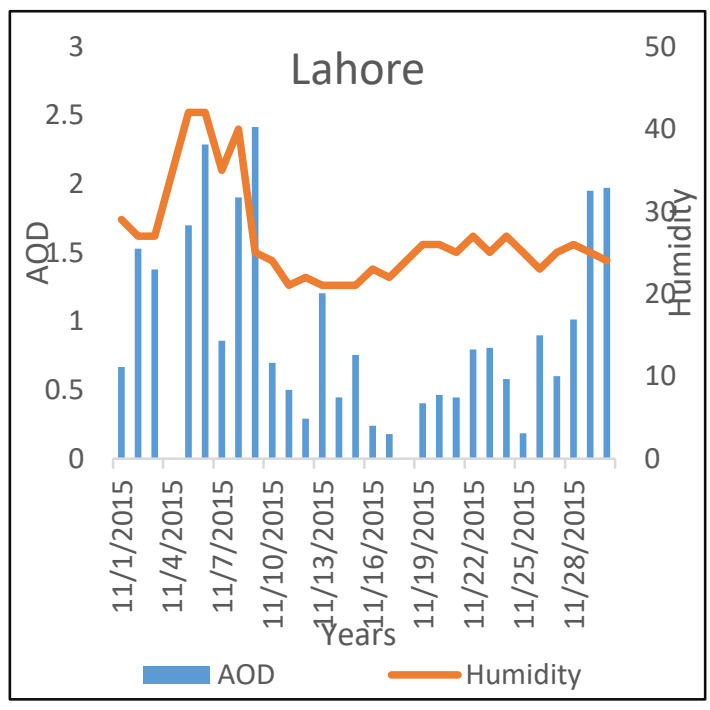

Fig. 14. AOD and humidity time series over Lahore during 2015.

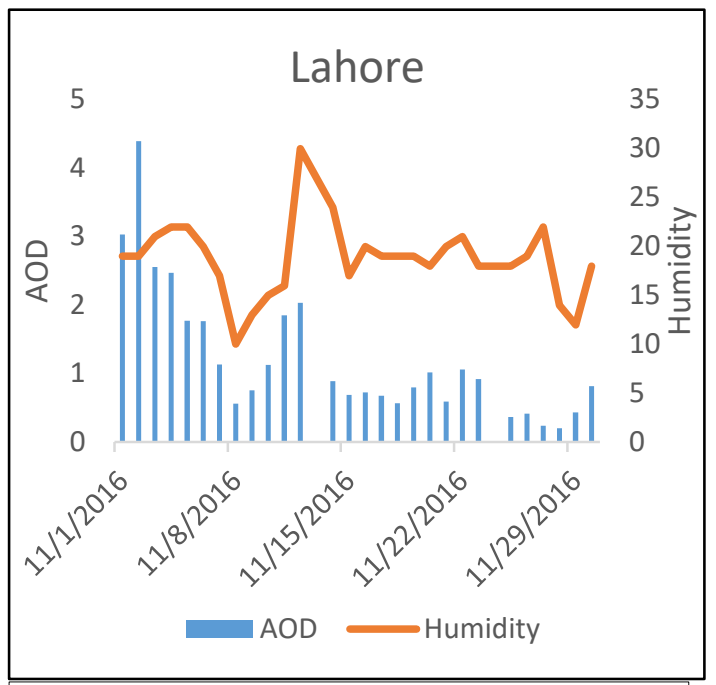

Fig. 15. AOD and humidity time series over Lahore during 2016.

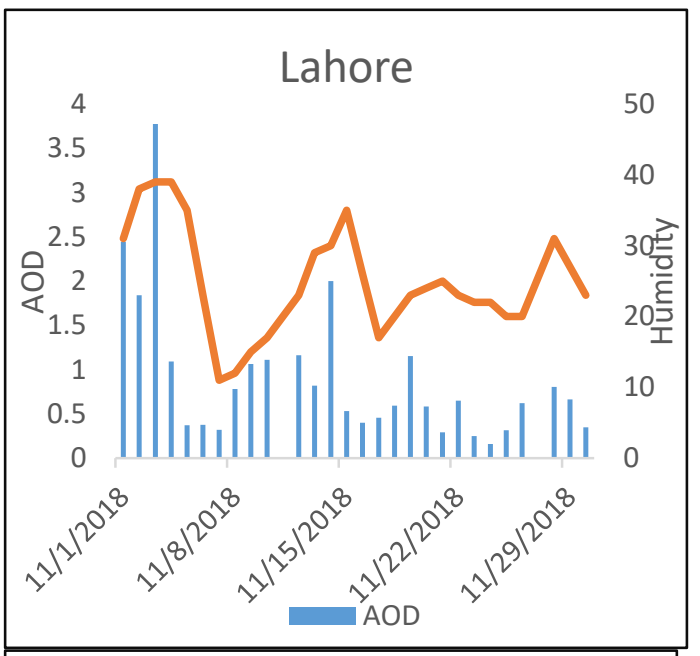

Fig. 16. AOD and humidity time series over Lahore during 2018.

\section{HYSPLIT Trajectories}

Backward HYSPLIT trajectories are calculated during the days of November when AOD was maximum for all 3 years. Trajectories are calculated at three different heights of $500 \mathrm{~m}, 1000 \mathrm{~m}$ and $1500 \mathrm{~m}$. GDAS data having spatial resolution of $0.5^{\circ}$ is used for computing backward HYSPLIT trajectories. It is the only available global 

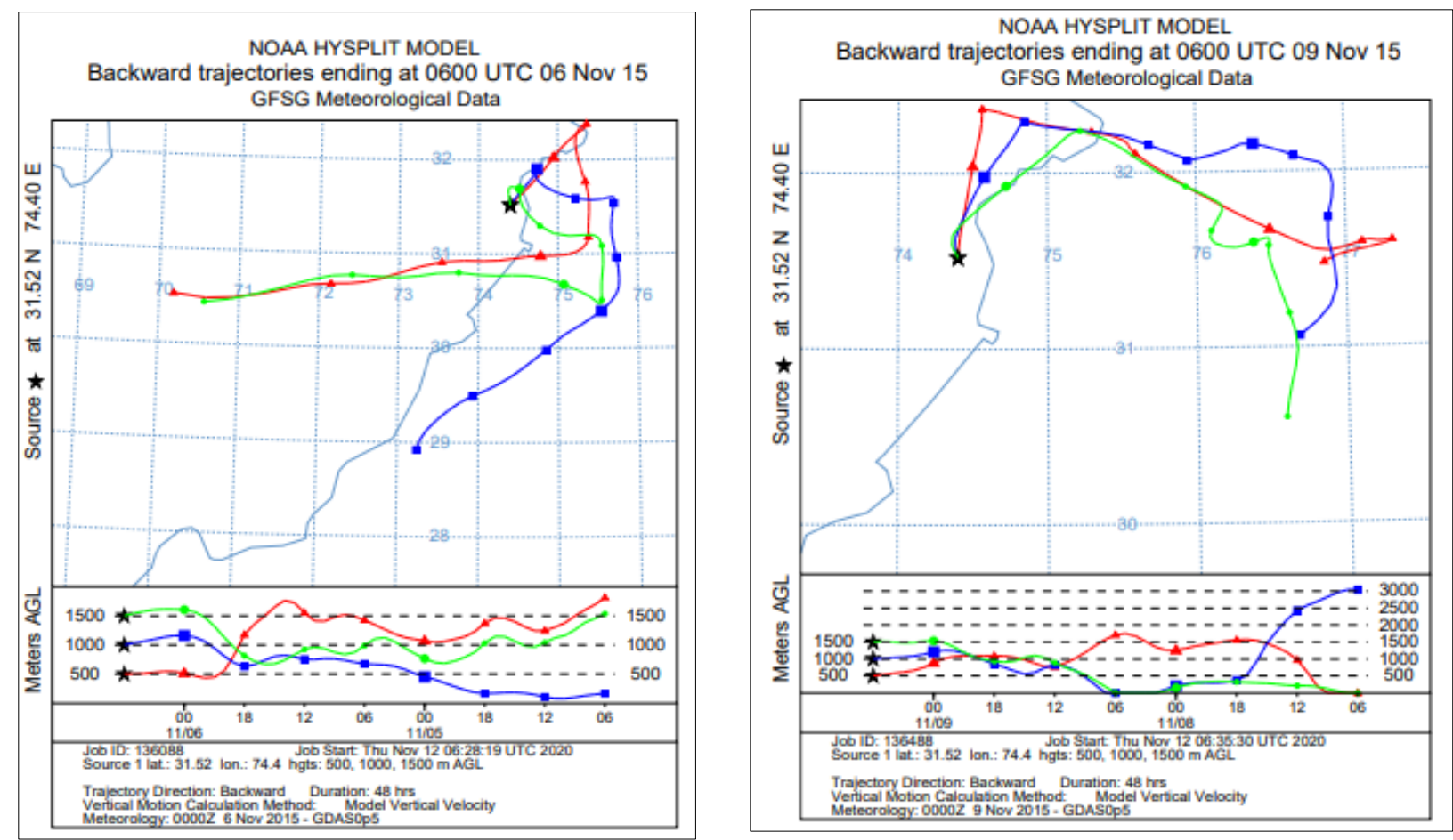

Fig. 17. HYSPLIT trajectories for the month of November 2015.
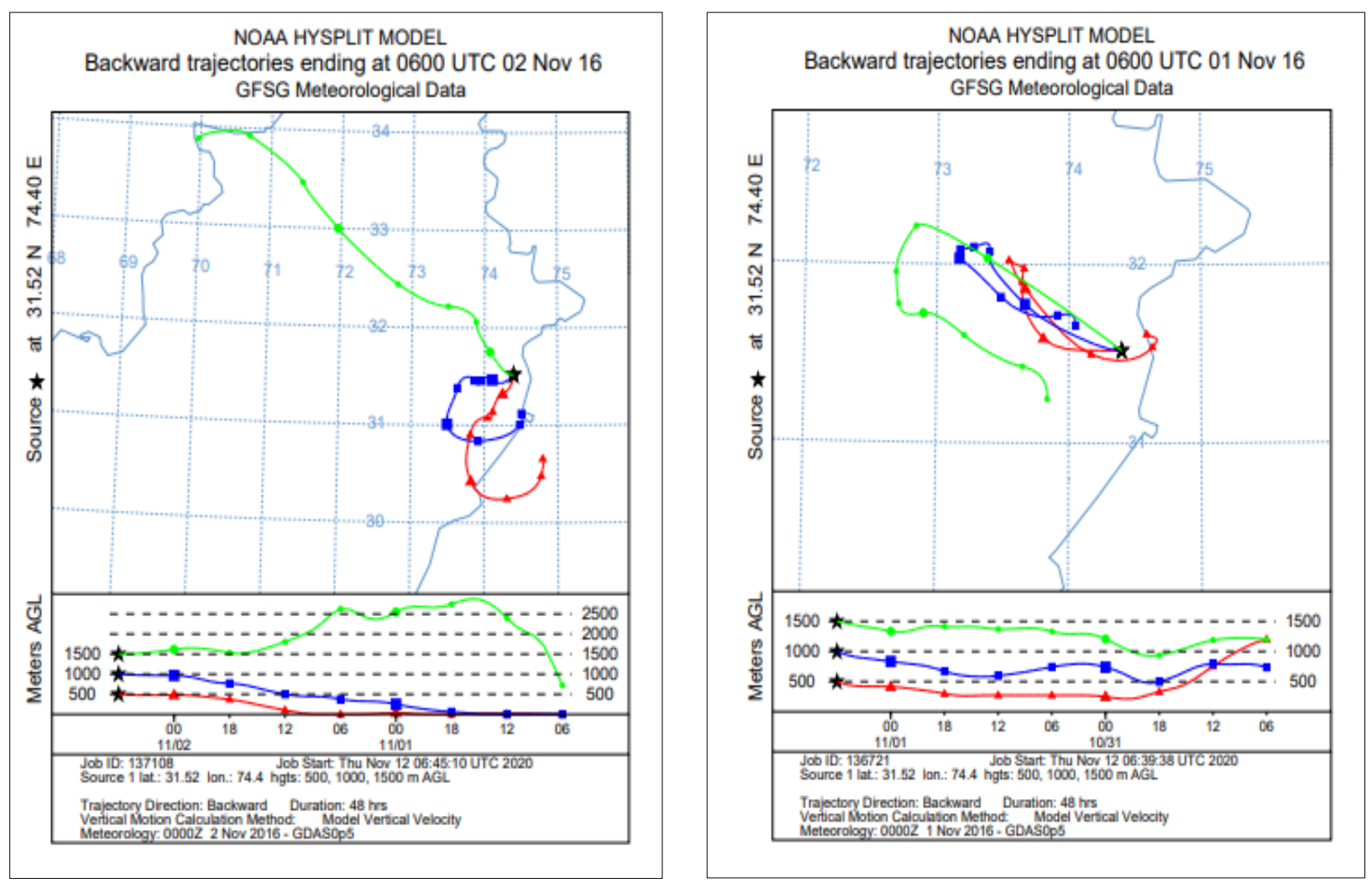

Fig. 18. HYSPLIT trajectories for the month of November 2016. 

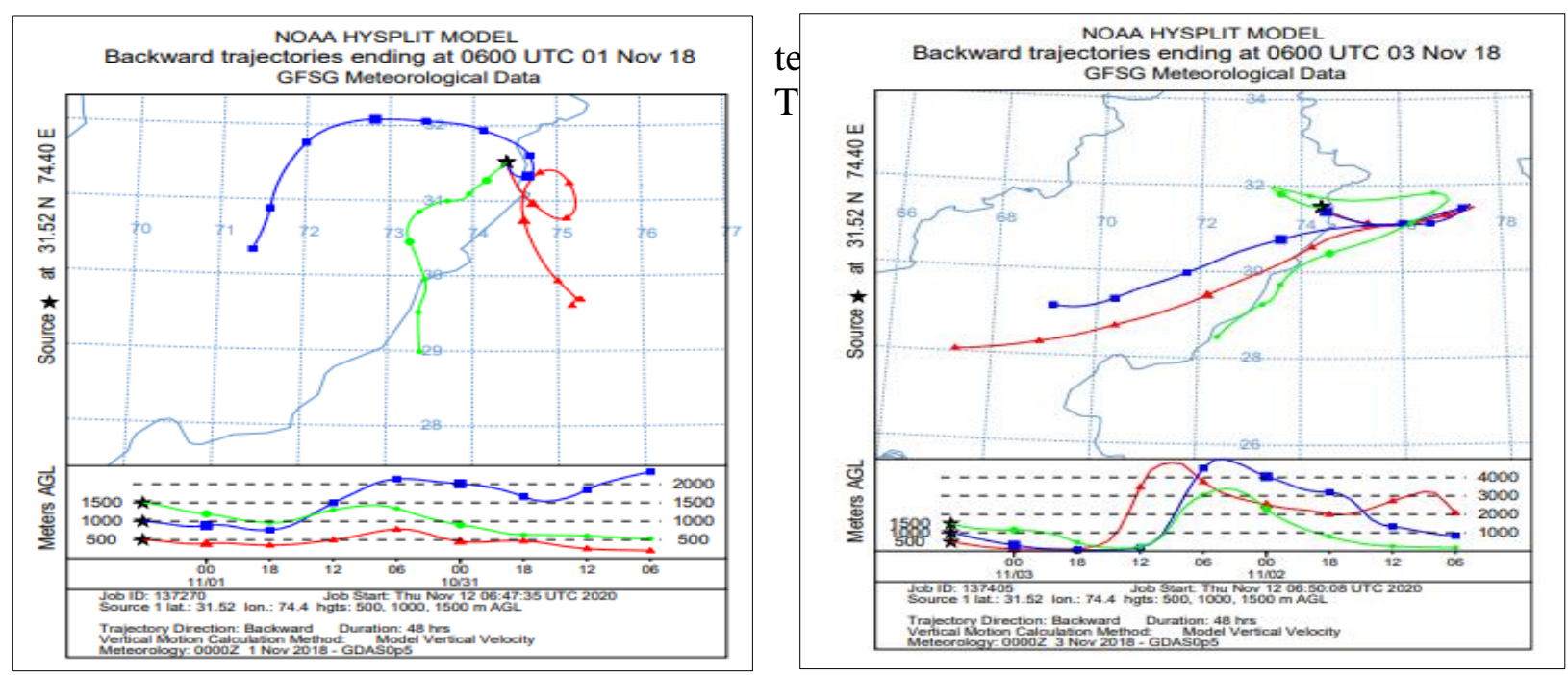

Fig. 19. HYSPLIT trajectories for the month of November 2018.

In 2018, AOD shows the maximum value on 3 November and then starts to decrease. FMF shows the same trend. data that have best spatial resolution to compute online trajectories for current location

Aerosols are not only a regional but a global problem due to their longrange transport by winds. Approximately 100 million tons of aerosols due to burning process are added in atmosphere annually. Lahore shares its southeast boundary with Indian region dominated by the combustion activities of biomass (Tariq \& Ali, 2016). Vehicular emission and crop residue burning significantly contribute to the total aerosol burden over northwest India (Singh et al., 2004). HYSPLIT trajectories during maximum AOD days suggest that mostly air masses are coming from Indian region, transporting $\mathrm{BC}$ aerosols to the study area. Lahore itself faces immense biomass burning phenomenon from heating and crop burning process. But the transported aerosols from Indian region provide favorable conditions for maximum aerosol deposition resulting in smog episodes over Lahore.

Vertical soundings (profiles) of wind speed and direction (wind flags), temperature (red line), and dew point

Soundings give us details about the general steadiness of the atmosphere and the location of temperature inversion aloft too which bounds the vertical fusion of pollutants.

Harmful pollutants emitted nearby the surface are enhanced by the shallow surface inversion and is very dangerous to the human health (Rolph, Stein and Stunder, 2017). Diagram shows the graphical illustration of moisture, pressure, density and temperature in a way that the main atmospheric energy conversions can be easily seen. This diagram includes numerous charts superimposed on each other.

Skew-T Log-P diagrams of the time period chosen for the study of smog show very low speed winds during maximum AOD days. Concentration of BC aerosols in atmosphere is strongly influenced by wind velocity. As stability is enhanced at day time, slow winds at surface reduce the rate of dispersion of particles from atmosphere (Jacobson \& Mark Z, 2002). Winds with higher velocity cause dispersion of aerosols by the process of dry deposition during summer months. Also, there is more vertical mixing of air in the form of convection or forced convection and more precipitation. 
In winter months, use of fossil fuel increases for heating purposes. Burning of crops in late autumn months is also practiced in south Asia (Zhang et al., 2015). Negative correlation between wind speed and concentrations of $\mathrm{BC}$ aerosols has been observed in Pakistan and in neighboring countries. It is also proved that wind speed increases in wet months as compared to dry months resulting in stronger aerosol dispersion (Dutkiewicz et al., 2009; Chen et al., 2016).

Maximum temperature on surface is 30 degrees suggesting the dominance of fine mode particles as $\mathrm{AE}$ is negatively correlated with temperature. In the month of November, which is considered most favorable for smog, average temperature, wind speed, visibility and dust storm frequency decreases. Whereas, humidity, $\mathrm{AE}$ and $\mathrm{AOD}$ increases indicating an increase in aerosol burden in atmosphere. Higher values of AE suggest the dominance of fine mode particles (Kaskaoutis \& Kambezidis, 2006; Tariq \& Ul-Haq, 2020).

A positive correlation of $\mathrm{AE}$ is proved with humidity while negative with temperature (Tariq \& Ul-Haq, 2020). Hence, fine mode particle's concentration increases with increase in relative humidity and decrease in temperature. Generally, there is a positive correlation between $\mathrm{BC}$ aerosols and relative humidity. Humidity values reaching up to $90 \%$ are favorable for

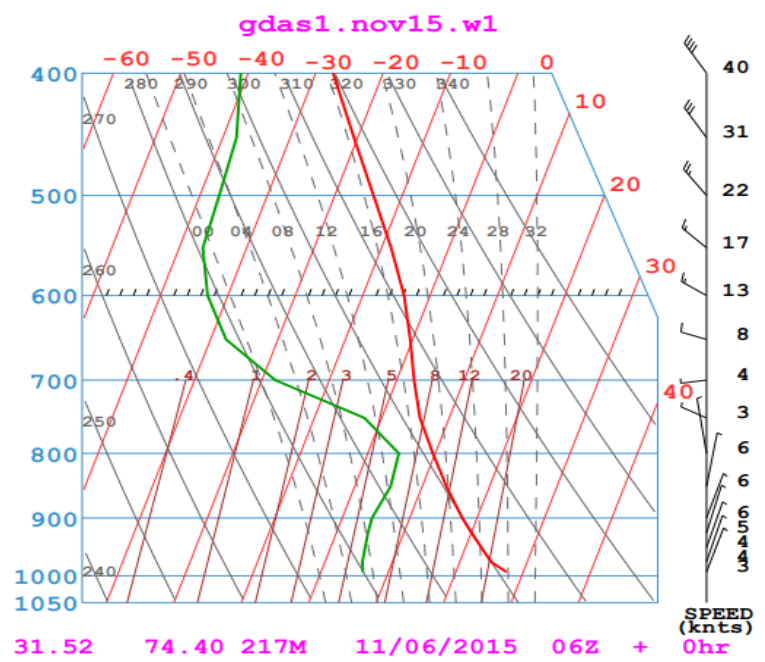

increase in BC concentration (Rajeevan et al., 2019), however, hygroscopic growth of particles starts resulting in decrease of visibility. If humidity increases further, the hygroscopic growth helps in the dispersion process as it may cause precipitation (Rajeevan et al., 2019). Over our research area, humidity is reaching up to $45 \%$ maximum. This humidity is not enough for precipitation but can cause decrease in visibility.

A noticeable difference between temperature and dew point temperature suggests the presence of dry air in lower troposphere. Keeping all these conditions in consideration, we can consider these days as smog events as there is neither wet nor dry deposition of aerosols is occurring. Therefore, maximum pollutants are present to contaminate the atmosphere.

In figure 20,21 and 22, dry adiabatic laps rate is shown in solid grey lines sloping top left to bottom right and temperature as red lines. Since there is not much difference in slope of temperature and dry adiabatic lapse rate, the atmosphere thus is supposed to have neutral stability in lower troposphere. Wind velocity and direction can be seen from the figure 20,21 and 22 , showing the same basic trend for the three years profile. The change in direction occurs near the surface due to the surface roughness and surface eddies.

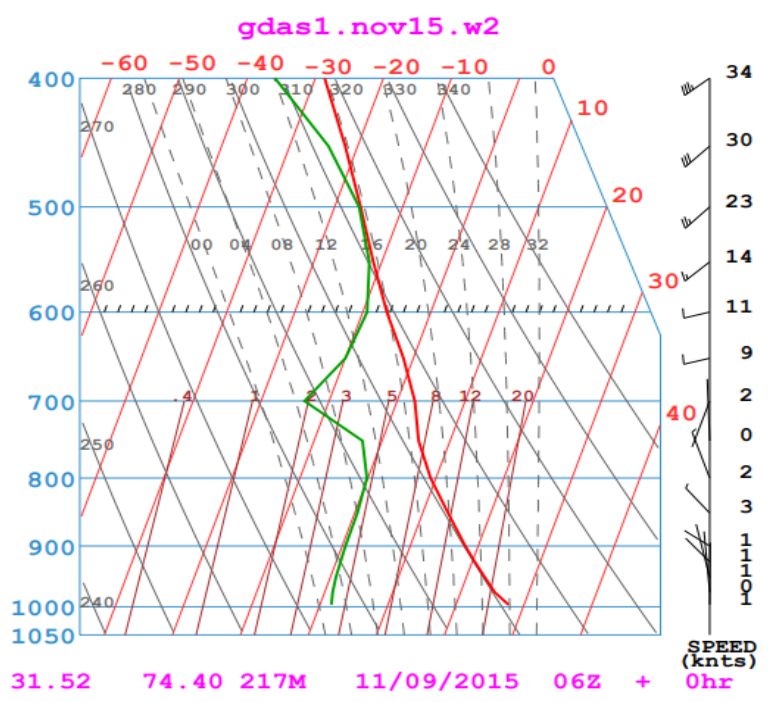

Fig. 20. Vertical sounding profile during selected days of Nov, 2015. 

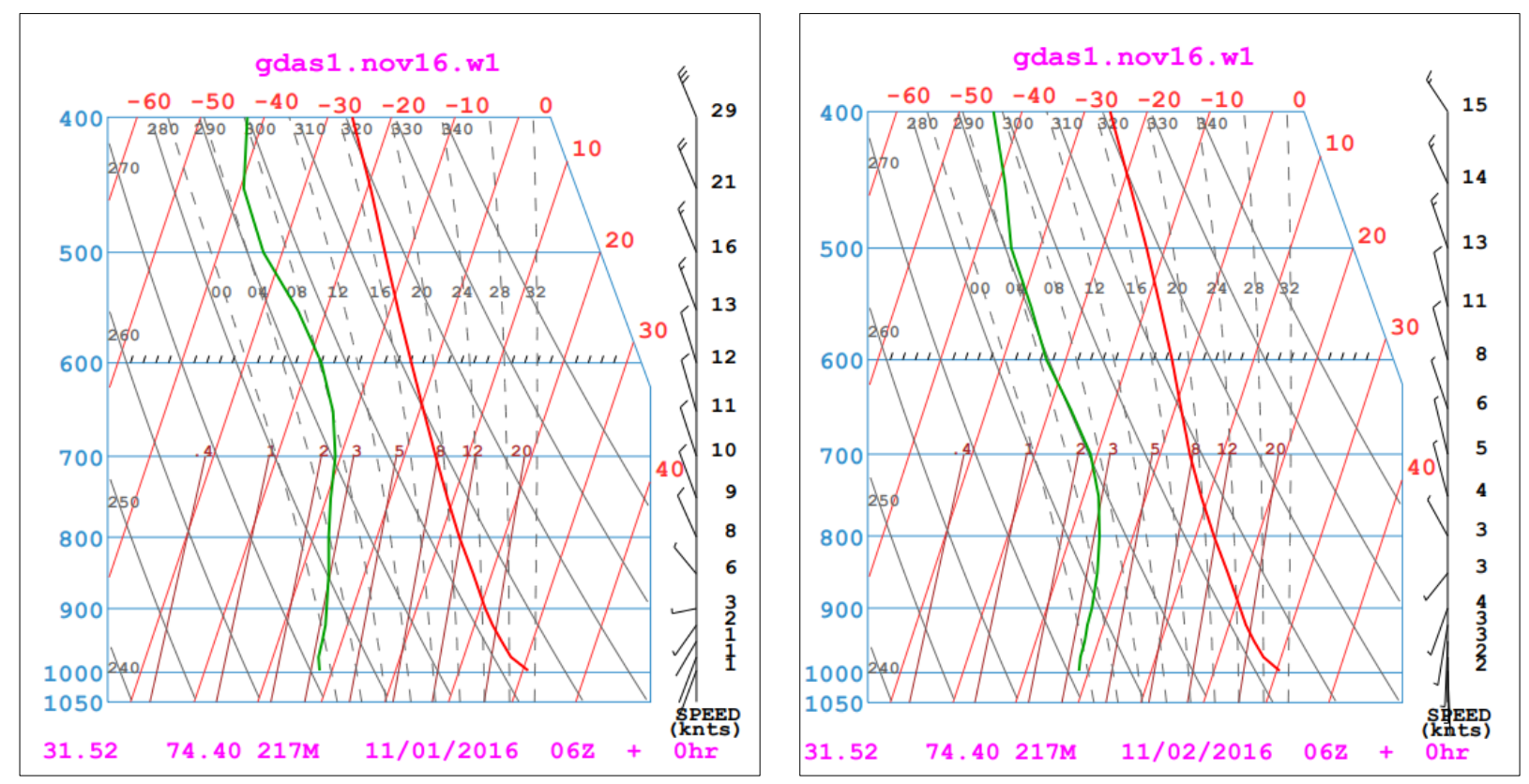

Fig. 21. Vertical sounding profile during selected days of Nov, 2016.
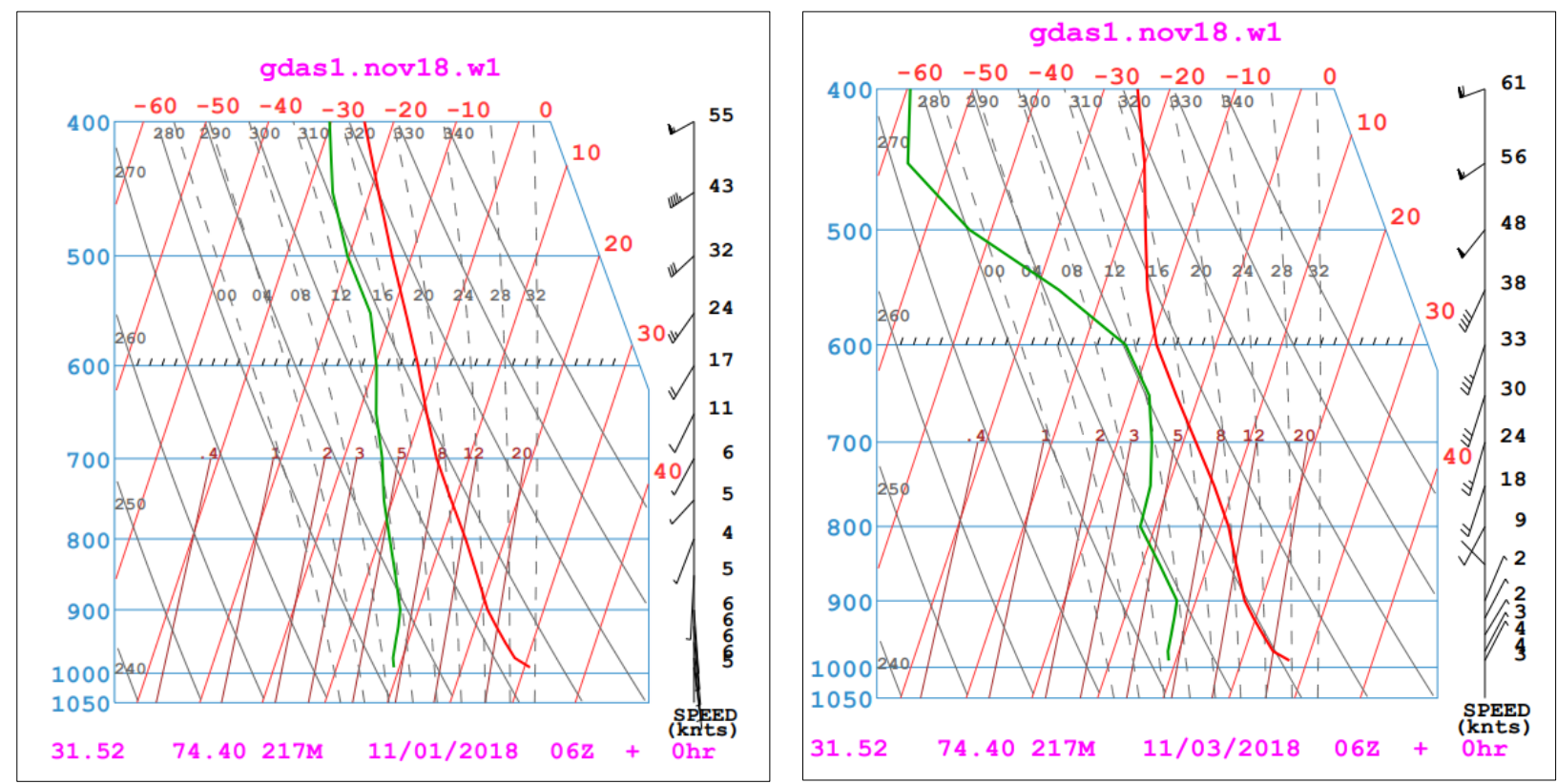

Fig. 22. Vertical sounding profile during selected days of Nov, 2018.

\section{Conclusions}

Aerosols are classified on the basis of FMF and SSA into six different types. One of the main aerosol types which is abundant in every smog episode is $\mathrm{BC}$ aerosol while dust is present throughout the year. Incomplete combustion of fossil fuels, biofuels and biomass generates $\mathrm{BC}$ aerosols. $\mathrm{BC}$ is considered as one of the main components responsible for radiational imbalance and climate change. Furthermore, time series of AOD during smog episodes is used to identify variability of aerosol burden in atmosphere. Backward trajectories from HYSPLIT model are used to trace the origin 
of aerosols during the days of maximum AOD. The aerosols detected over the city Lahore are mainly from biomass burning, soot emission, anthropogenic and different urban activities.

\section{References}

Ali, M., Tariq, S., Mahmood, K., Daud, A. and Batool, A., 2014. A study of aerosol properties over Lahore (Pakistan) by using AERONET data. Asia-Pacific Journal of Atmospheric Sciences, 50(2), pp.153-162.

Aloysius, M., Mohan, M., Suresh Babu, S., Parameswaran, K. and Krishna Moorthy, K., 2009, June. Validation of MODIS derived aerosol optical depth and an investigation on aerosol transport over the South East Arabian Sea during ARMEX-II. In Annales Geophysicae (Vol. 27, No. 6, pp. 2285-2296). Copernicus GmbH.

Al-Dousari, A.M. and Al-Awadhi, J., 2012. Dust fallout in northern Kuwait, major sources and characteristics. Kuwait Journal of Science, 39(2A), pp.171-187.

Ashiq, M.M., ur Rehman, H. and Khan, N.M., 2020. Impact of large diameter recharge wells for reducing groundwater depletion rates in an urban area of Lahore, Pakistan. Environmental Sciences, 79(17), pp.1-14.

Brimblecombe, P., 1978. Air pollution in industrializing England. Journal of the Air Pollution Control Association, 28(2), pp.115-118.

Bond, T.C., Bhardwaj, E., Dong, R., Jogani, R., Jung, S., Roden, C., Streets, D.G. and Trautmann, N.M., 2007. Historical emissions of black and organic carbon aerosol from energy-related combustion, 1850-2000. Global Biogeochemical Cycles, 21(2).
Chen, H., Cheng, T., Gu, X., Li, Z. and Wu, Y., 2016. Characteristics of aerosols over Beijing and Kanpur derived from the AERONET dataset. Atmospheric Pollution Research, 7(1), pp.162-169.

Draxler, R.R. and Hess, G.D., 1998. An overview of the HYSPLIT_4 modelling system for trajectories. Australian meteorological magazine, 47(4), pp.295308.

Dutkiewicz, V.A., Alvi, S., Ghauri, B.M., Choudhary, M.I. and Husain, L., 2009. Black carbon aerosols in urban air in South Asia. Atmospheric Environment, 43(10), pp.1737-1744.

Dubovik, O. and King, M.D., 2000. A flexible inversion algorithm for retrieval of aerosol optical properties from Sun and sky radiance measurements. Journal of Geophysical Research: Atmospheres, 105(D16), pp.20673-20696.

Giles, D.M., Holben, B.N., Tripathi, S.N., Eck, T.F., Newcomb, W.W., Slutsker, I., Dickerson, R.R., Thompson, A.M., Mattoo, S., Wang, S.H. and Singh, R.P., 2011. Aerosol properties over the IndoGangetic Plain: A mesoscale perspective from the TIGERZ experiment. Journal of Geophysical Research: Atmospheres, 116(D18).

Hameed, Z.A., 2020. Assessment of stack emissions during different phases of electric arc furnace steelmaking process. Kuwait Journal of Science, 47(1).

Higurashi, A. and Nakajima, T., 2002. Detection of aerosol types over the East China Sea near Japan from four-channel satellite data. Geophysical research letters, 29(17), pp.17-1.

Jacobson, M.Z., 2002. Control of fossil-fuel particulate black carbon and organic matter, 
possibly the most effective method of slowing global warming. Journal of Geophysical Research: Atmospheres, 107(D19), pp.ACH-16.

Kaskaoutis, D.G. and Kambezidis, H.D., 2006. Investigation into the wavelength dependence of the aerosol optical depth in the Athens area. Quarterly Journal of the Royal Meteorological Society: A journal of the atmospheric sciences, applied meteorology and physical oceanography, 132(620), pp.2217-2234.

Kim, J., Lee, J., Lee, H.C., Higurashi, A., Takemura, T. and Song, C.H., 2007. Consistency of the aerosol type classification from satellite remote sensing during the Atmospheric Brown Cloud-East Asia Regional Experiment campaign. Journal of Geophysical Research: Atmospheres, 112(D22).

Kedia, S., Ramachandran, S., Holben, B.N. and Tripathi, S.N., 2014. Quantification of aerosol type, and sources of aerosols over the Indo-Gangetic Plain. Atmospheric Environment, 98, pp.607-619.

Lee, J., Kim, J., Song, C.H., Kim, S.B., Chun, Y., Sohn, B.J. and Holben, B.N., 2010. Characteristics of aerosol types from AERONET sunphotometer measurements. Atmospheric Environment, 44(26), pp.31103117.

Mehmood, U. and Tariq, S., 2020. Globalization and CO 2 emissions nexus: evidence from the EKC hypothesis in South Asian countries. Environmental Science and Pollution Research, 27(29), pp.3704437056.

Mehmood, U., 2020. Globalization-driven CO 2 emissions in Singapore: an application of ARDL approach. Environmental Science and Pollution Research, pp.1-6.
Mehmood, U., Tariq, S., Ul-Haq, Z. and Meo, M.S., 2020. Does the modifying role of institutional quality remain homogeneous in GDP-CO 2 emission nexus? New evidence from ARDL approach. Environmental Science and Pollution Research, pp.1-8.

Mira-Salama, D., Grüning, C., Jensen, N.R., Cavalli, P., Putaud, J.P., Larsen, B.R., Raes, F. and Coe, H., 2008. Source attribution of urban smog episodes caused by coal combustion. Atmospheric Research, 88(3-4), pp.294-304.

Mishra, B.R., Hanrieder, N., Modi, A. and Kedare, S.B., 2020. Comparison of three models to estimate the slant path atmospheric attenuation in central receiver solar thermal plants under Indian climatic conditions. Solar Energy, 211, pp.10421052.

Nakajima, T., Tonna, G., Rao, R., Boi, P., Kaufman, Y. and Holben, B., 1996. Use of sky brightness measurements from ground for remote sensing of particulate polydispersions. Applied optics, 35(15), pp.2672-2686.

Nawazish, S., Bukhari, S.M., Muhammad, A., Khan, I.U., Alhassan, A.J., Hussain, M. and Zaidi, A., 2017. Correlation analysis of toxic metals on motorway and national highway. Kuwait Journal of Science, 44(2).

Rajeevan, K., Sumesh, R.K., Resmi, E.A. and Unnikrishnan, C.K., 2019. An observational study on the variation of black carbon aerosol and source identification over a tropical station in south India. Atmospheric Pollution Research, 10(1), pp.30-44.

Rolph, G., Stein, A. and Stunder, B., 2017. Real-time environmental applications and display system: READY. 
Environmental Modelling \& Software, 95, pp.210-228.

Sabbah, I., Al-Mudhaf, H.F., AlKandari, A. and Al-Sharifi, F., 2012. Remote sensing of desert dust over Kuwait: long-term variation. Atmospheric Pollution Research, 3(1), pp.95-104.

Shah, S.I.H., Nawaz, R., Ahmad, S. and Arshad, M., 2020. Sustainability Assessment of Modern Urban Transport and Its Role in Emission Reduction of Greenhouse Gases: A Case Study of Lahore Metro Bus. Kuwait Journal of Science, 47(2).

Stein, A.F., Draxler, R.R., Rolph, G.D., Stunder, B.J., Cohen, M.D. and Ngan, F., 2015. NOAA's HYSPLIT atmospheric transport and dispersion modeling system. Bulletin of the American Meteorological Society, 96(12), pp.2059-2077.

Singh, R.P., Dey, S., Tripathi, S.N., Tare, V. and Holben, B., 2004. Variability of aerosol parameters over Kanpur, northern India. Journal of Geophysical Research: Atmospheres, 109(D23).

Tariq, S., Ul-Haq, Z., 2020. Investigating the aerosol optical depth and angstrom exponent and their relationships with meteorological parameters over Lahore in Pakistan. Proceedings of the national academy of sciences, india section a: physical sciences, 90(5), pp.861-867.

Tariq, S. and Ali, M., 2015. Analysis of optical and physical properties of aerosols during crop residue burning event of October 2010 over Lahore, Pakistan. Atmospheric Pollution Research, 6(6), pp.969-978.

Tariq, S. and Ali, M., 2016. Satellite and ground-based remote sensing of aerosols during intense haze event of October 2013 over Lahore, Pakistan. Asia-Pacific Journal of Atmospheric Sciences, 52(1), pp.25-33.

Yu, X., Zhu, B. and Zhang, M., 2009. Seasonal variability of aerosol optical properties over Beijing. Atmospheric Environment, 43(26), pp.4095-4101.

Zhang, X.Y., Wang, J.Z., Wang, Y.Q., Liu, H.L., Sun, J.Y. and Zhang, Y.M., 2015. Changes in chemical components of aerosol particles in different haze regions in China from 2006 to 2013 and contribution of meteorological factors. Atmospheric Chemistry \& Physics, 15(22).

Submitted: $\quad 17 / 08 / 2020$

Revised: $\quad 18 / 11 / 2020$

Accepted: $\quad 19 / 12 / 2020$

DOI: $\quad 10.48129 /$ kjs.v48i4.10407 